\title{
SIMULTANEOUS SCREENING OF 5 ALLERGENS IN FOOD BY USING LIQUID CHROMATOGRAPHY TRIPLE QUADRUPOLE MASS SPECTROMETRY
}

\author{
Nguyen Thi Ha Binh ${ }^{1 *}$, Nguyen Thi Thu ${ }^{2}$, Dang Thi Ngoc Lan', \\ Nguyen Thi Hai ${ }^{3}$, Tran Cao Son ${ }^{1}$ \\ ${ }^{1}$ National Institute for Food Control \\ ${ }^{2}$ Hanoi University of Pharmacy \\ ${ }^{3}$ TanTrao University
}

Received in: 5/7/2019; Revised on: 23/8/2019;

Accepted on: 27/8/2019)

\section{Abstract}

The liquid chromatography tandem mass spectrometry with electrospray ionization (ESI) source in multiple reactions monitoring (MRM) mode has been used to detect five allergen including milk, egg, peanut, soyabean, and walnut in milk, dairy products, and confectionery. The allergenic proteins from food matrices were extracted with an extraction buffer $(50 \mathrm{mM}$ of TRIS- saline, $2 \mathrm{M}$ of urea, and $25 \mathrm{mM}$ of DTT) and then enzymatically digested with trypsin to form peptides. The peptides were eventually detected on a LC-MS/MS Triple Quad 5500 system from AB SCIEX. As a result, each allergen was characterized by a corresponding specific peptide. The limit of detection was of $3 \mu \mathrm{g} / \mathrm{g}$ for milk, $5 \mu \mathrm{g} / \mathrm{g}$ for peanut, $10 \mu \mathrm{g} / \mathrm{g}$ for soyabean and walnut and $20 \mu \mathrm{g} / \mathrm{g}$ for egg.

Keyword: $L C-M S / M S$, allergens, milk, egg, peanut, soyabean, walnut.

\section{INTRODUCTION}

Currently, food allergy is a major concern over the world. According to some studies in the US, the rate of food allergy in adults is 3\%, in children is $8 \%$ and tends to increase. In Vietnam, so far, there have not been accurate statistics. However, food allergy is also one of the common symptoms, especially in children. The major food allergens are peanut, milk, egg, wheat, soyabean, seed and seafood [1]. They account for $90 \%$ of all food allergies.

In order to make food avoidance easier for allergic consumers, food labeling regulations have been developed around the world such as the Food Allergen Labeling and Consumer Protection Act in the United States [2], the Directives 2003/89/EC [3] and 2007/68/EC [4] in the European Union (EU). Accordingly, the maximum allowable content of allergens in foods is 10 $\mathrm{mg} / \mathrm{kg}$ in Europe and in the United States [2], [3]. In Japan, the limit of detection of the ELISA method for determining allergens is $10 \mathrm{mg} / \mathrm{kg}$ [4]. In Vietnam, Joint Circular No. 34/2014/TTLTBYT-BNNPTNT-BCT on guiding the labeling of food, food additives and ready-to-pack processing aids requires the labeling of the composition of food ingredients. The presence of eggs, peanuts, soyabean, milk and etc., are required to be indicated [5]. Therefore, it is necessary to apply analytical methods with sufficient sensitivity and specificity to screen allergens.

\footnotetext{
*Tel:0988479022Ｅmail: habinhsp86@gmail.com
} 
At present, there are numbers of methods that have been used to determine allergens. They can be classified into three main groups: immunoassay method (IM), deoxyribonucleic acid analysis methods (DNA), and liquid chromatography tandem mass spectrometry method (LC-MS/MS). Although the LC-MS/MS method has not been widely used, it is gaining more and more attention to analyze allergens in food with the advantages of reliability and the ability to simultaneously identify multiple allergens. Among those, numbers of studies used mass spectrometry with Qtrap and Q-TOF mass analyzer, such as Poms et al. [6], Boo et al. [7], New et al. [8], and Weber et al. [10]. Qtrap and Q-TOF applications are very efficient in molecular weight determining, protein sequencing and protein screening. There has been no study using triple-quadrupole mass spectrometry. Nevertheless, it is considered a suitable alternative to screening allergens based on the identification of marker peptides in multiple reaction mornitoring mode.

Therefore, this study has been implemented with the goal of building a method for screening several allergens in food by liquid chromatography tandem mass spectrometry and applying the method in determining the presence of allergens in food products (milk, dairy products, confectionery).

\section{MATERIALS AND METHODS}

\subsection{Materials and standards}

The study focused on five allergens (eggs, milk, peanuts, soyabean and walnuts). These are the most common allergenic foods available in Vietnamese markets.

In the survey, samples including milk, dairy products, confectionery were taken randomly from different markets in Hanoi.

Standards were peptides extracted from natural material sources (eggs, milk, peanuts, soyabean seeds, walnuts) purchased at a supermarket in Hanoi. Acetonitrile and formic acid were of pure analytical grade for chromatography. n-Hexane, iodoacetamide (IA), dithiothreitol (DTT), urea, tris (hydroxymethyl) aminomethane (TRIS), sodium chloride, ammonium bicarbonate, and acetic acid were all analytical pure chemicals purchased from Merck. Trypsin (CAS No. 9002-07-7) was also purchased from Merck.

\subsection{Equipment}

The main equipment was the liquid chromatography tandem mass spectrometry system (Triple Quad 5500, SCIEX). Besides, a balance with accuracy of $0.1 \mathrm{mg}$ (MS-205DU, Mettler Toledo), a vortex mixer (Genius, IKA) and a centrifuge with maximum speed of $18000 \mathrm{rpm}$ (Mikro 220R, Hettich) were also employed in this study.

\subsection{Methods}

Standards (peptides) were obtained from egg, milk, soyabean, walnut and peanut materials according to Heik et al. [9]. The amount of $1 \mathrm{~g}$ of natural material was extracted with $10 \mathrm{~mL}$ of Tris extraction buffer and filtered through a membrane filter before testing on LC-MS/MS. The extract was used to optimize analytical conditions on LC-MS/MS system.

For every experiment, the amount of $1 \mathrm{~g}$ of the defatted sample was weighted into a $15 \mathrm{~mL}$ centrifuge tube, $10 \mathrm{~mL}$ of TRIS extraction buffer solution was added and the tube was shaken and centrifuged to collect the supernatant. The extract was diluted with $\mathrm{NH}_{4} \mathrm{HCO}_{3}$ solution $(100$ $\mathrm{mM}$ ) to a final concentration of approximately $1 \mathrm{mg}$ protein per $\mathrm{mL}$ (the total soluble protein concentration in the extract was determined by the Kjeldahl method). DTT solution (200 
$\mathrm{mM}$ ) was added to reduced disulfide bonds of protein molecules, then the cysteine alkylation was performed by adding $1 \mathrm{M}$ of IA solution. Trypsin (100 $\mu \mathrm{L}$ of $4 \mathrm{~g} / \mathrm{mL}$ solution in acetic acid) was used to digest proteins. The digestion was stopped with concentrated formic acid. The final extract was filtered through a $0.2 \mu \mathrm{m}$ filter before being analyzed on LC-MS/MS [9]. Due to the fact that the buffer solution greatly influences the extraction efficiency and trypsin concentration and digestion time mainly decide the digestion performance, optimal extraction buffer solution, trypsin concentration and digestion time were investigated.

Specificity and limit of detection (LOD) were evaluated according to the procedure of Esther Trullols et al [11].

\section{RESULTS AND DISCUSSIONS}

\subsection{Method development}

\subsubsection{Mass spectrometry conditions}

Peptide identification was carried out on ESI-LC-MS/MS with MRM transition for selecting precursor ions and product ions (Table 1). For the development of the MRM method, milk, egg, soya, peanut and walnut were extracted and digested with trypsin without further purification. These digests containing only one allergenic food were injected to identify suitable marker peptides. The recorded MS/MS spectra were submitted to database searches with the online version of MASCOT. The aim was to find peptides from allergens that reproducibly occurred in every digest and therefore could be used as protein marker in the MRM method.

Table 1. The MRM condition of five allergens

\begin{tabular}{|c|c|c|c|c|c|c|}
\hline No. & Allergic food & Protein & $\begin{array}{c}\text { Precursor ion } \\
(m / z)\end{array}$ & Charge & $\begin{array}{c}\text { Daughter } \\
\text { ion }(m / z)\end{array}$ & $C E$ \\
\hline \multirow{2}{*}{1} & \multirow{2}{*}{ Egg white } & \multirow{2}{*}{ Ovalbumin } & \multirow{2}{*}{673.4} & \multirow{2}{*}{+2} & 223.2 & 30 \\
\hline & & & & & 1095.6 & 25 \\
\hline \multirow{4}{*}{2} & \multirow{4}{*}{ Milk } & \multirow{2}{*}{ Casein $\alpha \mathrm{S} 1$} & \multirow{2}{*}{634.3} & \multirow{2}{*}{+2} & 249.2 & 30 \\
\hline & & & & & 991.3 & 23 \\
\hline & & \multirow{2}{*}{ Casein $\alpha \mathrm{S} 2$} & \multirow{2}{*}{598.3} & \multirow{2}{*}{+2} & 158.3 & 25 \\
\hline & & & & & 911.4 & 20 \\
\hline \multirow{4}{*}{3} & \multirow{4}{*}{ Peanut } & \multirow{2}{*}{ Ara h1 } & \multirow{2}{*}{688.8} & \multirow{2}{*}{+2} & 300.2 & 40 \\
\hline & & & & & 930.6 & 32 \\
\hline & & \multirow{2}{*}{ Ara h3/4 } & \multirow{2}{*}{684.5} & \multirow{2}{*}{+2} & 748.6 & 30 \\
\hline & & & & & 836.5 & 26 \\
\hline \multirow{2}{*}{4} & \multirow{2}{*}{ Soyabean } & \multirow{2}{*}{ Glycinin } & \multirow{2}{*}{575.2} & \multirow{2}{*}{+2} & 219.2 & 30 \\
\hline & & & & & 903.2 & 22 \\
\hline \multirow{2}{*}{5} & \multirow{2}{*}{ Walnut } & \multirow{2}{*}{ Jug r1 } & \multirow{2}{*}{688.2} & \multirow{2}{*}{+2} & 477.2 & 30 \\
\hline & & & & & 1147.4 & 25 \\
\hline
\end{tabular}


The following parameters were also selected: ion spray voltage (IS) at $5500 \mathrm{kV}$, source temperature at $400^{\circ} \mathrm{C}$, ion source gas 1 (GS1) at $20 \mathrm{psi}$, ion source gas 2 (GS2) at $20 \mathrm{psi}$, curtain gas at $25 \mathrm{psi}$, and collision gas at 8 psi. MRM mode has selected 1 precursor ion and 2 product ions including 1 ion for quantification (bold part) and 1 ion for qualitative (not bold part) for each substance.

\subsubsection{Liquid chromatographic conditions}

The peptides can be separated by using $\mathrm{C} 18$ reverse phase chromatographic column $[6,7$, $8,9]$. The Symmestry C18 column $(150 \mathrm{~mm} \times 4.6 \mathrm{~mm} \times 3.5 \mu \mathrm{m})$ and the corresponding pre-column (Waters) were used in this study.

Mobile phase was the gradient of acetonitrile and $0.1 \%$ formic acid in water. The LC run started 5\% acetonitril within $1 \mathrm{~min}$, then increased to $90 \%$ acetonitril within 7 min and maintained at this rate within $4 \mathrm{~min}$. The mobile phase was eventually returned to the original condition and stabilized for 3 min to the next measurement. Total analysis time was 15 minutes. The result was shown in Figure 1.

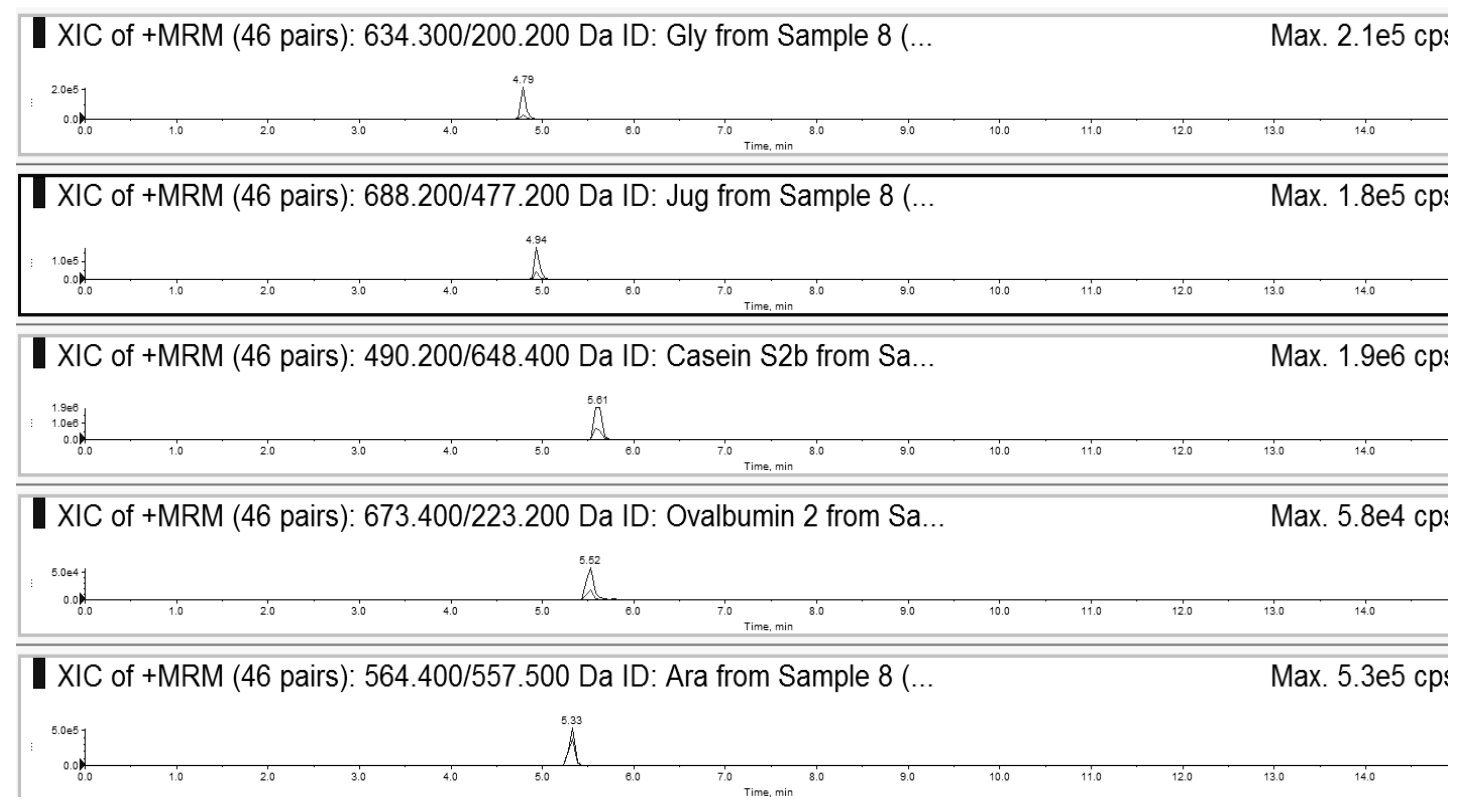

Fig 1. Chromatography of allergens (Glycinin in soyabeans, Jug in walnuts, casein in milk, Ovabumin in egg whites, Ara in peanuts)

Even though, the retention times of the substances were relatively similar, the substances were completely separated from each other.

\subsubsection{Sample preparation}

\subsubsection{Protein extraction}

Wheat flour used as blank sample was spiked with five allergic commodities (milk, egg, soy, peanut and walnut) at the concentration of $1 \mathrm{mg} / \mathrm{g}$ (protein content is determined by Kjeldahl method). Based on previous studies, two procedures for extracting proteins from the sample were tested:

- Procedure 1, Heick et al. [9]: extraction buffer 1: $50 \mathrm{mM}$ of TRIS-HCl buffer, $\mathrm{pH}$ 8.2.

- Procedure 2, Boo et al. [7]: extraction buffer 2: $2 \mathrm{M}$ of urea, $50 \mathrm{mM}$ of Tris-buffered saline 
(TBS), and $25 \mathrm{mM}$ of dithiothreitol (DTT)].

After extraction, the soluble protein concentrations were determined by applying the Kjeldahl method. The results were shown in Table 2.

Table 2. Soluble protein concentration in extracts from two procedures

\begin{tabular}{|c|l|c|c|c|c|c|}
\hline \multirow{2}{*}{ No. } & \multirow{2}{*}{ Procedure } & \multicolumn{5}{|c|}{ Soluble protein concentrations (\%) } \\
\cline { 3 - 7 } & & Egg & Milk & Peanut & Soyabean & Walnut \\
\hline 1 & Procedure 1 & 7.8 & 75.0 & 42.2 & 30.1 & 31.2 \\
\hline 2 & Procedure 2 & 12.3 & 99.5 & 50.6 & 45.8 & 42.8 \\
\hline
\end{tabular}

Accordingly, the extraction buffer 2 gave higher extraction efficiency than the extraction buffer 1 . The presence of urea might help break down the hydrogen bonding between molecules, while DTT cut the disulfite (-S-S-) link between polypeptide chains, thereby increasing protein solubility. Therefore, the proteins extracted by buffer 2 were selected for the next investigation.

\subsubsection{Trypsin concentration}

Cake samples containing egg, milk and soyabean were used to investigate different concentrations of trypsin from $0.4 ; 2 ; 4 ; 10 ; 20 \mathrm{mg} / \mathrm{mL}$. The hydrolysis time was fixed at 12 hours. The results were summarized in Figure 2.

The results showed that the signal of the allergens was highest at trypsin concentration of $4.0 \mathrm{mg} / \mathrm{mL}$ for all types of allergens. It could be concluded that the optimal trypsin concentration for hydrolysis was $4.0 \mathrm{mg} / \mathrm{mL}$.

\subsubsection{Hydrolysis time}

Different hydrolysis times ( 8 hours, 12 hours, 15 hours and 18 hours) were evaluated in the hydrolysis step of cake samples. The results were summarized in Figure 3.

Survey results showed that the hydrolysis efficiency after 12 hours was significantly higher than that after 8 hours, no significant difference among the hydrolysis durations of 12 hours, 15 hours and 18 hours. Moreover, the signal of milk allergen tended to reduce. Therefore, the hydrolysis duration of 12 hours was selected for saving sample preparation time.

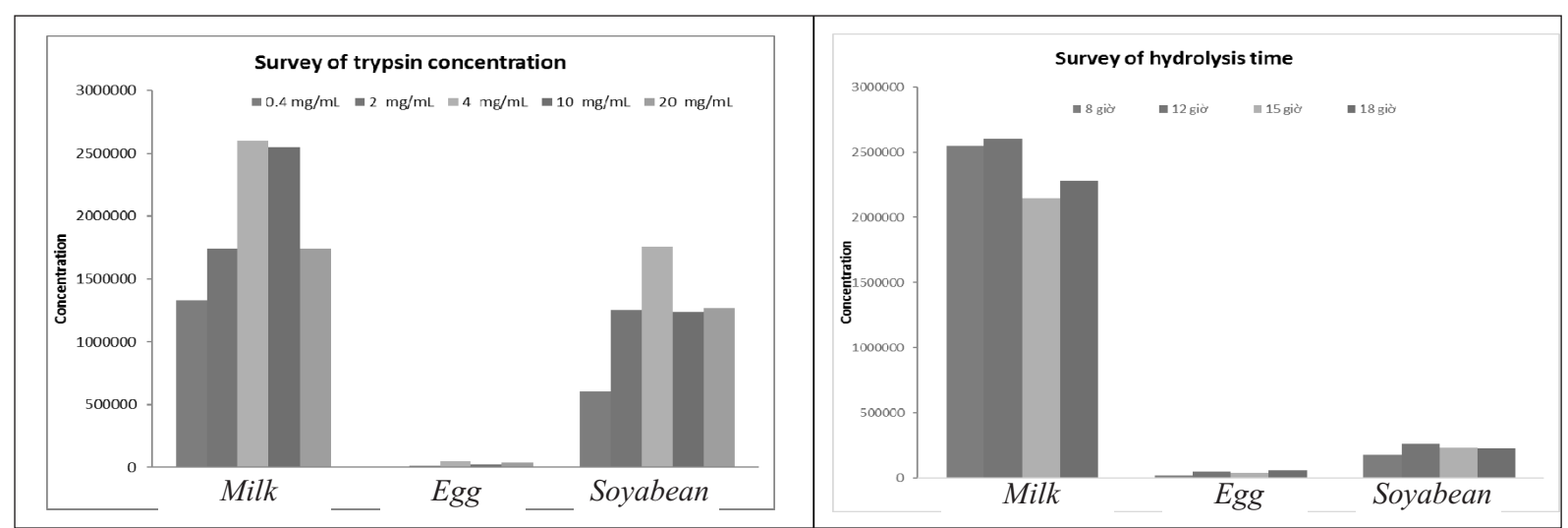

Fig 2. Survey results of trypsin concentration

Fig 3. Survey results of hydrolysis time

Optimal sample preparation is selected as follows:

The amount of $1 \mathrm{~g}$ defatted sample was transferred into a $15 \mathrm{~mL}$ centrifuge tube. The tube was added with $10 \mathrm{~mL}$ of extraction buffer, sonicated at room temperature for $10 \mathrm{~min}$, shaken 
within $15 \mathrm{~min}$, and then centrifuged at $6000 \mathrm{rpm}$ within $5 \mathrm{~min}$. The supernatant was retained and the extraction process was repeated once.

The two extracts were combined to form extract A. The soluble protein concentration in the extract was determined by Kjeldahl method. Extract A was diluted with $\mathrm{NH}_{4} \mathrm{HCO}_{3}$ solution $(100 \mathrm{mM})$ to an approximate concentration of $1 \mathrm{mg}$ of protein per $\mathrm{mL}$. The diluted extract was added with $500 \mu \mathrm{L}$ DTT $200 \mathrm{mM}$, shaken for 1 minute, incubated 45 minutes at room temperature to reduce disulfide bridge. Subsequently, the alkylation was performed by adding $400 \mu \mathrm{L}$ IA solution (1M), and incubated winthin 45 minutes in the dark at room temperature. The solution was, then, added with $200 \mu \mathrm{L}$ DTT solution $(200 \mathrm{mM}), 500 \mu \mathrm{L} \mathrm{NH}_{4} \mathrm{HCO}_{3}(200$ $\mathrm{mM})$ and $100 \mu \mathrm{L}$ trypsin $\left(4 \mathrm{~g} / \mathrm{mL}\right.$ in $50 \mathrm{mM}$ acetic acid) and incubated for 12 hours at $37^{\circ} \mathrm{C}$. The digestion was stopped by adding $2 \mu \mathrm{L}$ concentrated formic acid. The final extract was injected into the HPLC after filtering through a $0.2 \mu \mathrm{m}$ filter.

\subsection{Method validation}

\subsubsection{Specificity}

Blank samples (wheat flour), standard materials, and spiked samples at the concentrations of $1 \mathrm{mg} / \mathrm{g}$ per allergen (milk, eggs, peanuts, soyabeans, walnuts) were analyzed.

The chromatogram of blank sample contained no signal of allergens. The retention time of the allergen peaks in the spiked samples corresponded to the retention time of the peaks in the standard materials. In addition, the ion ratio of the spiked sample was consistent with the ion ratio of the corresponding standard material, meeting the requirements of the EU regulation $657 / 2002 / \mathrm{EC}$. The results showed that the method satisfied the requirement for specificity (Figure 4 and Table 3).

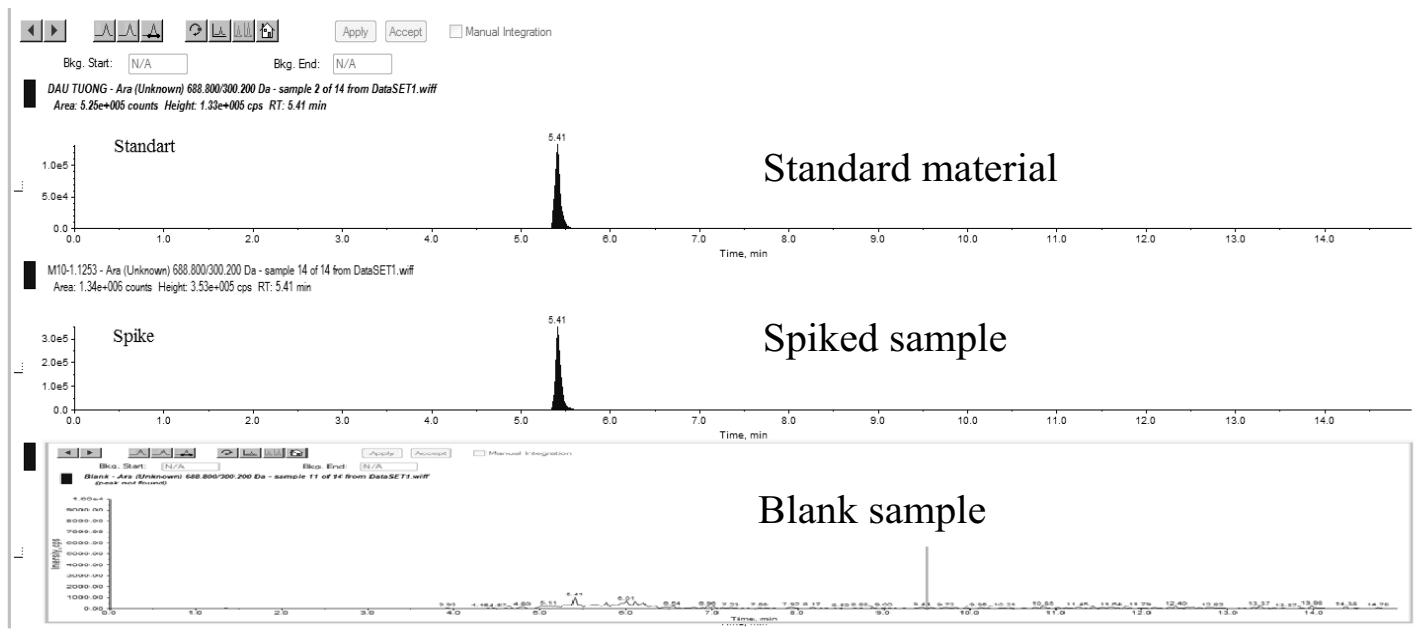

Fig 4. The chromatogram of the blank sample, spiked sample, standard material of peanut

Table 3. The ion ratio of allergens

\begin{tabular}{|c|c|c|c|c|c|c|}
\hline No. & Allergen & Protein & $\begin{array}{c}\text { Parent } \\
\text { ion }\end{array}$ & Ion ratio & Ratio & Tolerance \\
\hline 1 & Egg & Ovalbumin & 673 & $1095.6 / 223.2$ & $30 \%$ & $\pm 25 \%$ \\
\hline 2 & Milk & Casein $\alpha$ S1 & 634 & $991.4 / 249.2$ & $20 \%$ & $\pm 25 \%$ \\
\hline 3 & Peanut & Ara h1 & 688.8 & $930.6 / 300.2$ & $25 \%$ & $\pm 25 \%$ \\
\hline
\end{tabular}




\begin{tabular}{|c|c|c|c|c|c|c|}
\hline No. & Allergen & Protein & $\begin{array}{c}\text { Parent } \\
\text { ion }\end{array}$ & Ion ratio & Ratio & Tolerance \\
\hline 4 & Soyabean & Glycinin & 575.2 & $903.2 / 219.2$ & $17 \%$ & $\pm 30 \%$ \\
\hline 5 & Walnut & Jug r1 & 688.2 & $1147.4 / 477.2$ & $20 \%$ & $\pm 25 \%$ \\
\hline
\end{tabular}

Blank sample (wheat flour) and spiked sample at the estimated limit of detection (LOD) $(10 \mu \mathrm{g} / \mathrm{g}$ and $20 \mu \mathrm{g} / \mathrm{g})$ were repeatedly analysed $(\mathrm{n}=6)$ in order to determine the signal to noise ratio (S/N). LOD (S/N $\geq 3$ ) of the allergens was of $3 \mu \mathrm{g} / \mathrm{g}$ for milk, $5 \mu \mathrm{g} / \mathrm{g}$ for peanuts, $10 \mu \mathrm{g} / \mathrm{g}$ for walnuts and soyabeans, and $20 \mu \mathrm{g} / \mathrm{g}$ for eggs.

\subsection{Application of methods to screen several allergens in foods}

The method has been applied for the screening of 45 samples taken from the markets. Samples included cake, milk, dairy products, and confectionery. The results showed that 44 samples containing milk components were identified to contain casein, 12 samples with egg composition were identified to contain ovalbumin. Samples with various ingredients such as eggs, milk and soyabean could also be accurately identified by the method. It can be concluded that the method is completely applicable to screening the presence of allergens.

\section{CONCLUSION}

The procedure of screening the allergens based on liquid chromatography and triple-quadrupole mass spectrometry in multiple reaction monitoring mode has been successfully developed and evaluated. The method allowed identification of allergens (peanuts, walnuts, eggs, milk and soyabeans) at concentration ranges from $3 \mu \mathrm{g} / \mathrm{g}$ to $20 \mu \mathrm{g} / \mathrm{g}$. The results implied that the method can be used to screen different allergens in foods with good selectivity and sensitivity.

\section{REFERRENCE}

1. N. EFSA Panel on Dietetic Products and Allergies (NDA) (2014), "Scientific Opinion on the evaluation of allergenic foods and food ingredients for labelling purposes", EFSA journal, vol. 12, no. 11, p. 3894.

2. S. L. Taylor and J. L. Baumert (2015), "Worldwide food allergy labeling and detection of allergens in processed foods", Food allergy: Molecular basis and clinical practice, vol. 101, pp. $227-234$.

3. S. M. Gendel (2012), "Comparison of international food allergen labeling regulations", Regulatory Toxicology and Pharmacology, vol. 63, no. 2, pp. $279-285$.

4. M. Shoji, R. Adachi, and H. Akiyama (2018), "Japanese Food Allergen Labeling Regulation: An Update", Journal of AOAC International, vol. 101, no. 1, pp. 8 - 13.

5. Joint Circular No. 34/2014 / TTLT-BYT-BNNPTNT-BCT (2014), "Guidelines for labeling of food, food additives and ready-to-pack food processing aids".

6. R. E. Poms, C. L. Klein, and E. Anklam (2004), "Methods for allergen analysis in food: a review", Food additives and contaminants, vol. 21, no. 1, pp. $1-31$.

7. C. C. Boo, C. H. Parker, and L. S. Jackson (2018), "A Targeted LC-MS/MS Method for the Simultaneous Detection and Quantitation of Egg, Milk, and Peanut Allergens in Sugar Cookies", Journal of AOAC International, vol. 101, no. 1, pp. 108 - 117. 
8. L. S. New, R. Baghla, A. Schreiber, J. Stahl-Zeng, and H.-F. Liu (2015), "Qualitative LCMS/MS Analysis of 13 Food Allergens in a Single Injection on the QTRAP ${ }^{\circledR} 4500$ System", SCIEX Application note.

9. J. Heick, M. Fischer, and B. Pöpping (2011), "First screening method for the simultaneous detection of seven allergens by liquid chromatography mass spectrometry", Journal of Chromatography A, vol. 1218, no. 7, pp. 938 - 943.

10. D. Weber, P. Raymond, S. Ben-Rejeb, and B. Lau (2006), "Development of a Liquid Chromatography - Tandem Mass Spectrometry Method Using Capillary Liquid Chromatography and Nanoelectrospray Ionization - Quadrupole Time-of-Flight Hybrid Mass Spectrometer for the Detection of Milk Allergens", Journal of Agricultural and Food Chemistry, vol. 54, no. 5, pp. $1604-1610$.

11. Esther Trullols, Itziar Ruisa' nchez, F. Xavier Rius (2004), "Validation of qualitative an alytical methods", Trends in Analytical chemical, vol. 23, No. 23.

Tóm tắt

\title{
ÚNG DụNG PHƯớ PHÁP SẮC KÝ LỎNG KHỐI PHỔ BA TỨ CựC ĐỂ SÀNG LỌC ĐỔNG THỜI 05 CHẤT DI NGUYÊN TRONG THỤ'C PHẨM
}

\author{
Nguyễn Thị Hà Bình ${ }^{1}$, Nguyễn Thị Thu², Đặng Thị Ngọc Lan ${ }^{2}$ \\ Nguyễn Thị Hải ${ }^{3}$, Trần Cao Sơn ${ }^{1}$ \\ ${ }^{1}$ Viện Kiểm nghiệm an toàn vệ sinh thực phẩm quốc gia \\ ${ }^{2}$ Trường Đại học Dược Hà Nọi \\ ${ }^{3}$ Trường Đại học Tân Trào
}

Phương pháp sắc ký lỏng ghép khối phổ ba tứ cực sử dụng nguồn ion hóa phun điện tử (ESI) với chế độ giám sát nhiều phản ứng $(\mathrm{MRM})$ đã được sử dụng để phát hiện năm chất gây dị ứng bao gồm sữa, trứng, đậu phộng, đậu nành và hạt óc chó trong sữa, sản phẩm sữa và bánh kẹo các loại. Các protein gây dị ứng trong các mầu thực phẩm được chiết xuất bằng dung dịch đệm (TRIS- saline $50 \mathrm{mM}$, urê $2 \mathrm{M}$ và DTT $25 \mathrm{mM}$ ), cắt mạch protein để tạo thành các peptide bằng trypsin, sau đó phân tích các peptide trên hệ thống LC-MS/MS Triple Quad 5500 của $\mathrm{AB}$ SCIEX. Mỗi chất gây dị ứng được xác minh bởi một peptide đặc trưng tương ứng. Giới hạn phát hiện của phương pháp là $3 \mu \mathrm{g} / \mathrm{g}$ đối với sữa, $5 \mu \mathrm{g} / \mathrm{g}$ đối với đậu phộng, $10 \mu \mathrm{g} / \mathrm{g}$ đối với đậu tương và hạt óc chó và $20 \mu \mathrm{g} / \mathrm{g}$ đối với trứng.

Tù khóa: LC-MS/MS, chất dị nguyên, sũa, trưng, đậu phộng, đậu nành, hạt óc chó. 